\title{
Degradation Kinetics of Anthocyanins in Shalgam Beverage ${ }^{\#}$
}

\author{
Adnan Bozdoğan ${ }^{*}$, Kurban Yaşar $^{2}$ \\ ${ }^{1 *}$ Department of Food Engineering, Engineering Faculty, Osmaniye Korkut Ata University, 80000 Osmaniye, Turkey \\ Corresponding author, E-mail: bozdogan@osmaniye.edu.tr, ORCID: https://orcid.org/0000-0002-3612-5898 \\ ${ }^{2}$ Department of Food Engineering, Engineering Faculty, Osmaniye Korkut Ata University, 80000 Osmaniye, Turkey \\ E-mail: kurbanyasar@osmaniye.edu.tr
}

\begin{tabular}{|c|c|}
\hline A R T I C L E I N F O & A B S T R A C T \\
\hline $\begin{array}{l}\text { Research Article } \\
\text { Received : 04/10/2018 } \\
\text { Accepted : 08/11/2018 } \\
\text { Keywords: } \\
\text { Shalgam beverage } \\
\text { Anthocyanin } \\
\text { Kinetics } \\
\text { Temperature } \\
\text { Fermentation }\end{array}$ & $\begin{array}{l}\text { This research was performed to elucidate the effects of temperature on the degradation kinetics of } \\
\text { anthocyanins in shalgam beverage. Shalgam beverage was produced according to traditional } \\
\text { production method. Then, it was kept at three different temperatures }\left(65^{\circ} \mathrm{C}, 75^{\circ} \mathrm{C} \text {, and } 85^{\circ} \mathrm{C}\right) \text { for } \\
12 \text { hours, and the relevant quantities of anthocyanins were determined thereafter. The research } \\
\text { revealed that degradation of the anthocyanins was well described with a } 1 \text { st-order reaction kinetics } \\
\text { model and the } \mathrm{R}^{2} \text { values varied in the range of } 0.9059-0.9715 \text {. Activation energy of the reaction } \\
\text { was determined to be } 48537 \text { Joule/mole. The half-lives of anthocyanins at } 65^{\circ} \mathrm{C} \text { and } 75^{\circ} \mathrm{C} \text {, and } \\
85^{\circ} \mathrm{C} \text { were found to be } 138.63,136.72 \text {, and } 51.57 \text {, respectively. Compared the half-life periods at } \\
\text { different temperatures, anthocyanins were found to be more resistant at } 65^{\circ} \mathrm{C} \text { and } 75^{\circ} \mathrm{C} \text { than at } \\
85^{\circ} \mathrm{C} \text {. }\end{array}$ \\
\hline
\end{tabular}

\#This work was presented to the conference (III. International Conference on Engineering and Natural Science) held on 3-7 May 2017

(c) (1) (9) This work is licensed under Creative Commons Attribution 4.0 International License

\section{Introduction}

Shalgam beverage, a lactic acid fermentation product, is a red colour, cloudy, and sour tasty drink. In the production of shalgam, black carrot, bulgur flour, yeast, rock salt, turnip and water are used. Black carrots are the main raw material for the production of shalgam, $10-20 \%$ is added at the beginning of the fermentation to obtain sufficient acidity and colour at the end of the fermentation. Colouring matter of anthocyanin that passes through black carrots during fermentation gives the red colour to shalgam beverage. Anthocyanins are water-soluble natural colouring compounds that give color to a variety of fruits, vegetables and flowers colour in their own tones of pink, red, blue, and violet (Canbaş and Fenercioğlu, 1984; Canbaş and Deryaoğlu, 1993; Tanguler, 2010; Tanguler and Erten, 2012a; Tanguler and Erten, 2010).

Shalgam beverage mainly produced in Adana, Mersin, Hatay, Osmaniye and Kahramanmaras. In recent years, its production has spread into other regions including Istanbul, Ankara and İzmir, also its consumption has increased. The produced shalgam beverage in Turkey is both consumed in the domestic market and exported to the external market. Thus, quality of the Shalgam has become important (Erten et al., 2008; Tanguler and Erten, 2012b).
Anthocyanins are significant compounds in terms of both quality and health. Anthocyanins as natural colouring materials are an alternative to synthetic colouring materials and used as additives in various foods. Anthocyanins are most commonly used for the foods including soft drinks, jams, ice cream, yoghurt, ready soup etc. in the European Union countries (Mazza and Brouillard, 1987; Costa et al., 2000).

Anthocyanins are important due to their beneficial pharmacological properties and health benefits. It is asserted that anthocyanin-rich red fruits and extracts have antibiotic therapeutic properties. These properties of anthocyanins are related to their anti-oxidant activities (Costa et al., 2000: Ayed et al., 2000). It has been emphasized in pharmacy that anthocyanins have beneficial health effects such as reduction of heart-related diseases and anti-cancer activity (Giusti and Wrolstad, 2001). Kong et al. (2003) stated that anthocyanins are therapeutic effect in various bloodstream disorders and some eye diseases. Especially cyanide glycosides have been reported to exhibit anti-oxidative, anti-mutagenic and anticarcinogenic activity (Galvano et al., 2004) 
Product acceptability depends on the colour properties expected from the product itself. The most important factor leading anthocyanins to break down is temperature. The high temperature applied during both processing and storage of the product causes the anthocyanins to break down (Giusti and Wrolstad, 2001; Bozdogan and Canbas, 2009).

Studies on the degradation kinetics of anthocyanins are required in terms of the application point of view. This investigation was performed to elucidate the effects of temperature on the degradation kinetics of anthocyanins in shalgam beverage.

\section{Materials and Methods}

Black carrots, bulgur flour, bread yeast, salt and water were used in the production of shalgam beverage. Black carrots were purchased from the local dealer. Other raw materials were also supplied from the market. The studies were carried out at Osmaniye Korkut Ata University Food Engineering Laboratory (Osmaniye, Turkey).

As can be seen in Figure 1, the carrots $(15 \%)$ were washed, cleaned, and peeled in the first stage. Then, those carrots cut into thin slices. The bulgur flour (3\%), rock salt $(1.2 \%)$ and yeast $(0.2 \%)$ were mixed and kneaded by adding water until the produced dough was brought to consistency. Then, it has been left to ferment in a 20 litter plastic containers at $25^{\circ} \mathrm{C}$. Lactic acid fermentation was carried out spontaneously, and the fermentation lasted for 25 days. At the end of fermentation process, shalgam beverage was filtered and transferred to containers. Shalgam samples were stored at 3 different temperatures $\left(65^{\circ} \mathrm{C}, 75^{\circ} \mathrm{C}\right.$, and $\left.85^{\circ} \mathrm{C}\right)$ for 12 hours. The amount of total anthocyanin was determined by taking samples from shalgam beverage during storage. Experiments were carried out in two replicates.
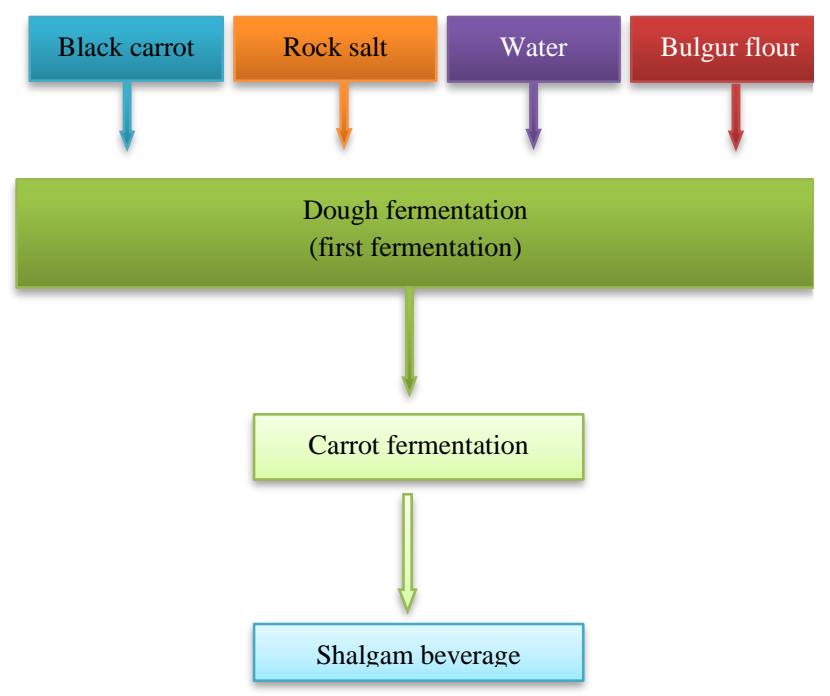

Figure 1 Shalgam Beverage Production Flow Chart (Erten et al., 2008, Tanguler and Erten, 2010)

\section{Anthocyanin Analysis}

Shalgam beverage was filtered, and its total anthocyanin was analysed by $\mathrm{pH}$ differential method. The samples were measured with a spectrophotometer (Shimadzu, Shimadzu Spectrophotometer UV-1800,
Kyoto, Japan) at wavelengths of 510 and $700 \mathrm{~nm}$. Anthocyanin content was calculated using extinction coefficient of $26900 \mathrm{~L} \mathrm{~cm}^{-1} \mathrm{mg}^{-1}$ and a molecular weight of 449.2 for Cyanidin-3-glucoside (Giusti and Wrolstad, 2001).

Analysis of total phenol compounds: Analysis of total phenol compounds was performed by measuring with infra-red spectrophotometer at $765 \mathrm{~nm}$ wavelength according to Folin Ciocalteu method. The results were presented in gallic acid (Singleton and Rossi, 1965).

Dry matter analysis: Dry matter in the shalgam beverage was determined according to Ough and Amerine (1988).

Total acidity: Total acidity was determined by titration method, and the relevant results were presented in lactic acid (Ough and Amerine, 1988).

$p H$ value: The $\mathrm{pH}$ values of extract and shalgam beverage samples were measured directly using a glass electrode $\mathrm{pH}$ meter (ThermoScientific Orion 2 Star CG 710) (Ough and Amerine, 1988).

Kinetics of colour degradation: The first-order reaction rates, constants $(\mathrm{k})$ and half-lives $\left(\mathrm{t}_{1 / 2}\right)$, and the time needed for $50 \%$ degradation of anthocyanins were calculated with the following equations:

$$
\begin{aligned}
& C=C_{0} \cdot \exp (-k t) \\
& t_{1 / 2}=\frac{\ln 2}{k}
\end{aligned}
$$

Where $\mathrm{C}_{0}$ is the initial anthocyanin content $(\mathrm{mg} / \mathrm{L})$, and $\mathrm{C}$ is the anthocyanin content $(\mathrm{mg} / \mathrm{L})$ after $\mathrm{t}$ minute heating at a given temperature.

The activation energy is calculated according to the Arrhenius equation (3)

$$
k=k_{0} \cdot \exp \left(-\frac{E a}{R T}\right)
$$

Where, Ea is the Arrhenius activation energy ( $\mathrm{kJ} / \mathrm{mole})$, $\mathrm{k}_{0}$ is a pre-exponential factor; $\mathrm{R}$ is the universal gas constant $(8.314 \mathrm{~J} /$ mole $\mathrm{K})$, and $\mathrm{T}$ is absolute temperature (K).

\section{Results and Discussion}

The composition of shalgam beverage is given in Table 1. The results are similar to prior studies. Deryaoğlu (2005) reported that $\mathrm{pH}$, total acidity, total dry matter and total phenol compounds varied in the range of 3.8-3.49, 9.6611.38 (g/L), 26.0-26.6 (g/L), 629-726 (mg/L), respectively. Canbaş and Fenercioğlu (1984) also stated that $\mathrm{pH}$, total acidity and dry matter compounds varied in the range of 3.50-3.78, 4.14-6.44 (g/L) and 30-35 (g/L), respectively.

Anthocyanins provides an attractive red colour for the red coloured fruits (strawberry, cherry, raspberry etc.) and vegetables (black carrot, red beet etc.), juices and red wines. Anthocyanins are important compounds in terms of both quality and health. Anthocyanins in fruits and vegetables pass into the product in varying amounts depending on temperature of the environment, $\mathrm{pH}$ value, amount of oxygen, application of enzyme, pressing process of piece size and amount of raw material (Mazza and Brouillard, 1987; Bozdogan and Canbas, 2009). 
Amounts of anthocyanin were determined at three different temperatures $\left(65^{\circ} \mathrm{C}, 75^{\circ} \mathrm{C}\right.$ and $\left.85^{\circ} \mathrm{C}\right)$ for 2-hour period with 12 hour intervals. Anthocyanin degradation was followed by a first-order reaction model.

Table 1 Composition of shalgam beverage

\begin{tabular}{l|c}
\hline $\mathrm{pH}$ & 3.45 \\
Total acidity $(\mathrm{g} / \mathrm{L})^{\mathrm{ae}}$ & 7.15 \\
Total dry matter $(\mathrm{g} / \mathrm{L})$ & 26.4 \\
Total phenol compounds $(\mathrm{mg} / \mathrm{L})^{\mathrm{b}}$ & 650 \\
\hline
\end{tabular}

a: lactic acid, b: gallic acid

Table 2 Degradation kinetics of anthocyanins

\begin{tabular}{l|lll}
\hline $\mathrm{T}\left({ }^{\circ} \mathrm{C}\right)$ & $\mathrm{k}(1 / \mathrm{h})$ & $\mathrm{t}_{1 / 2}(\mathrm{~h})$ & $\mathrm{R}^{2}$ \\
\hline 65 & 0.0507 & 136.715 & 0.9715 \\
75 & 0.05 & 138.629 & 0.9059 \\
85 & 0.1344 & 51.573 & 0.9207 \\
\hline
\end{tabular}

T: Temperature $\left({ }^{\circ} \mathrm{C}\right), \mathrm{K}$ : Reaction rate constant $(1 / \mathrm{h}), \mathrm{t}_{1 / 2}:$ Half-lives $(\mathrm{h})$

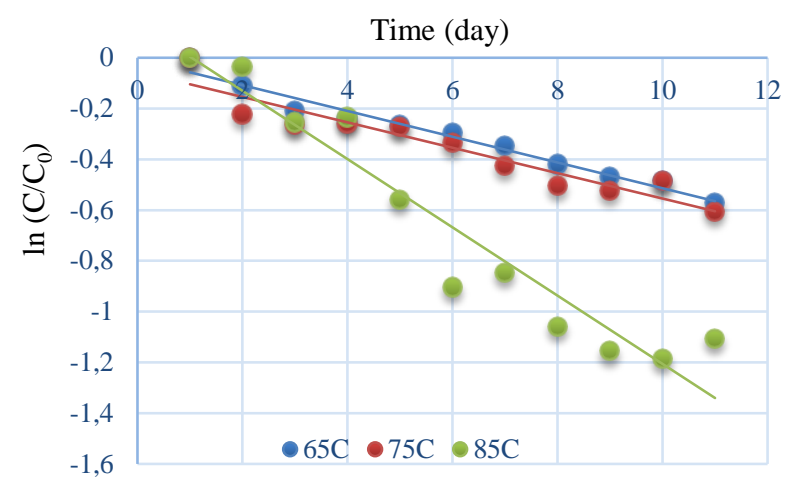

Figure 2 Degradation kinetics of shalgam anthocyanins

As can be seen in Figure 2 and Table 2, the $\mathrm{R}^{2}$ values varied in the range of $0.9059-0.9715$, and the results were found to be compatible with the 1st-order reaction kinetics model. Our study complies with previous studies. The previous studies also noted that degradation of anthocyanins due to temperature complies with 1st-order kinetics model (Cemeroglu et al.,1994; Garzon and Wrolstad, 2002; Kirca et al., 2007; Cao et al., 2011).

The half-lives of the anthocyanins at temperatures of $65^{\circ} \mathrm{C}$ and $75^{\circ} \mathrm{C}$ were found to be 136.72 and 138.63 hours, respectively, whereas those at $85^{\circ} \mathrm{C}$ were found to be 51.57 hours. Kirca et al. (2007) have added black carrot juices to fruit juices and examined the anthocyanins' breakdown kinetics. For this purpose, samples were heat treated at $70^{\circ} \mathrm{C}, 80^{\circ} \mathrm{C}$ and $90^{\circ} \mathrm{C}$ and stored at $4^{\circ} \mathrm{C}, 20^{\circ} \mathrm{C}, 37^{\circ} \mathrm{C}$. The anthocyanins were determined to be more stable at $70^{\circ} \mathrm{C}$ and $80^{\circ} \mathrm{C}$ for heat treatment and at $4^{\circ} \mathrm{C}$ for storage temperature. The half-lives of anthocyanins were observed to be $25.1,12.6$ and 5.6 hours at the temperatures of $70^{\circ} \mathrm{C}$, $80^{\circ} \mathrm{C}$ and $90^{\circ} \mathrm{C}$, respectively. The half-lives found in the above-mentioned study may be short compared to this study, which may be due to the composition of the products being studied. According to the half-lives, the anthocyanins were found to be more resistant at temperatures of $65^{\circ} \mathrm{C}$ and $75^{\circ} \mathrm{C}$ than at $85^{\circ} \mathrm{C}$.

Activation energies were calculated by plotting $\ln (\mathrm{k})$ against the reciprocal absolute temperature $(1 / \mathrm{T})$.
The activation energy was determined to be $\mathrm{Ea}=48537$ Joule/mole. Kirca et al. (2007) reported that the activation energy of the anthocyanins in the $7-90^{\circ} \mathrm{C}$ heat treated samples varied between 42100-78100 Joule/mole, whereas the activation energy of the anthocyanins in the $4-37^{\circ} \mathrm{C}$ stored samples varied between 65900-94700 Joule/mole. Cao et al. (2011) applied heat treatment to blood orange water at $70-90^{\circ} \mathrm{C}$ and determined the activation energy value of anthocyanins as 55810 Joule/mole.

\section{Conclusion}

One of the important quality criteria in shalgam beverages is the anthocyanins that color shalgam beverages. The degradation kinetics of anthocyanins at $65^{\circ} \mathrm{C}, 75^{\circ} \mathrm{C}$ and $85^{\circ} \mathrm{C}$ were investigated. The results indicated that the breakdown of anthocyanins complied with 1st-order kinetics model. Heat-treatment at $65^{\circ} \mathrm{C}$ and $75^{\circ} \mathrm{C}$ provided similar results in terms of half-life periods. However, compared to these temperatures, the breakdown of anthocyanins was faster at $85^{\circ} \mathrm{C}$. The anthocyanins were found to be more stable at $65^{\circ} \mathrm{C}$ and $75^{\circ} \mathrm{C}$ than at $85^{\circ} \mathrm{C}$.

\section{Conflict of Interest}

The authors declare no conflict of interest.

\section{References}

Ayed N, Yu HI, Lacroix M. 2000. "Using Gamma Irradiation for the Recovery of Anthocyanins from Grape Pomace". Radiation Physics and Chemistry, 57(3):277-279.

Bozdogan A, Canbas A. 2009. "Effect of Sulphur Dioxide, Ethyl Alcohol, Maceration Temperature and Time on Extraction of Phenolic Compounds of Vitis vinifera L. Cvs Öküzgözü and Bogazkere Grapes in Model Wine Solutions". Asian Journal of Chemistry, 21(4): 2835-2844.

Canbaş A, Deryaoğlu A. 1993. "Şalgam Suyunun Üretim Tekniği ve Bileşimi Üzerine Bir Araştırma”. Doğa, 17:119-129.

Canbaş A, Fenercioğlu H. 1984. "Şalgam Suyu Üzerinde Bir Araştırma". Glda, 9(5):279-286.

Cao, SQ, Liang LIU, Pan SY. 2011. "Thermal Degradation Kinetics of Anthocyanins and Visual Color of Blood Orange Juice”. Agricultural Sciences in China, 10(12), 1992-1997.

Cemeroglu B, Velioglu S, Isık S. 1994. "Degradation Kinetics of Anthocyanins in Sour Cherry Juice and Concentrate". Journal of Food Science, 59(6):1216-1218.

Costa CT, Horton D, Margolis SA. 2000. "Analysis of Anthocyanins in Foods by Liquid Chromatog-Rraphy, Liquid Chromatography-Mass Spectrometry and Capillary Electrophoresis". Journal of Chromatography A, 881: 403410.

Deryaoğlu A. 2005. "Şalgam Suyu Üretiminde $\mathrm{NaCl}$ Yerine $\mathrm{KCl}$ Kullanarak Sodyum Miktarını Azaltma Olanakları".Gida/The Journal of Food, 30(5):335-341.

Erten H, Tangüler H, Canbaş A. 2008. "A Traditional Turkish Lactic Acid Fermented Beverage: Shalgam". Food Reviews International, 24:352-359.

Galvano, F., La Fauci, L., Lazzarino, G., Fogliano, V., Ritieni, A., Ciappellano, S., Galvano, G. 2004. "Cyanidins: Metabolism and Biological Properties". The Journal of Nutritional Biochemistry, 15(1):2-11.

Garzon GA, Wrolstad RE. 2002. "Comparision of the Stability of Pelargonidin-Based Anthocyanins in Strawberry Juice and Concentrate". Journal of Food Science, 67(5), 1288-1299. 
Giusti M, Wrolstad ER. 2001. Characterization and Measuremant of Anthocyanins by UV-Visible Spectroscopy, Current Protocols in Food Analytical Chemistry, John Wiley \& Sons, Inc. New York, NY, Unit F1.2, p. 1-13.

Kırca A, Özkan M, Cemeroğlu B. 2007.” Effects of Temperature, Solid Content and $\mathrm{pH}$ on the Stability of Black Carrot Anthocyanins". Food chemistry, 101(1), 212-218.

Kong JM, Chia LS, Goh NK, Chia TF, Brouillard R. 2003. "Analysis and Biological Activities of Anthocyanins". Phytochemistry, 64(5):923-933.

Mazza G, Brouillard R. 1987. "Recent Development in the Stabilizition of Anthocyanins in Food Products". Food Chemistry, (25):207-225.

Ough CS, Amerine, M.A. 1988.” Methods for Analysis of Musts and Wines". John Wiley and Sons, New York.

Singleton VL, Rossi JA. 1965. "Colorimetry of Total Phenolics with Phosphomolybdic-Phosphotungstic Acid Reagents." American journal of Enology and Viticulture, 16(3): 144-158.
Tangüler H. 2010. "Şalgam Suyu Üretiminde Etkili Olan Laktik Asit Bakterilerinin Belirlenmesi ve Şalgam Suyu Üretim Tekniğinin Geliştirilmesi”. Çukurova Üniversitesi, Fen Bilimleri Enstitüsü, Doktora Tezi. 367s, Adana. Türkiye.

Tanguler H. Erten, H. 2012a. "Chemical and microbiological characteristics of shalgam (şalgam): a traditional turkish lactic acid fermented beverage". Journal of Food Quality, 35(4), 298-306.

Tanguler H, Erten H. 2012b."'Occurrence and Growth of Lactic Acid Bacteria Species During the Fermentation of Shalgam (Salgam), a Traditional Turkish Fermented Beverage". LWTFood Science and Technology, 46(1):36-41.

Tangüler H, Erten H. 2013. "Selection of potential autochthonous starter cultures from shalgam, a traditional Turkish lactic acid-fermented beverage". Turkish Journal of Agriculture and Forestry, 37(2): 212-220. 